\title{
Pengaruh Penyajian Laporan Keuangan Daerah dan Aksesibilitasnya Terhadap Transparansi dan Akuntabilitas Pengelolaan Keuangan Daerah Di Pemerintahan Kabupaten Kepulauan Talaud
}

\author{
Dedy Aries Poae \\ David P. E. Saerang
}

\begin{abstract}
At the time of onset of regional autonomy in the hope that emerges is more independent local governments in the implementation of government activities and conduct development in their respective areas. Government Regulation Number 24 of 2005 Government Accounting Standards neighbor besides achieving good governance is also the answer to anticipation the financial reporting guidelines that can be generally accepted.

The research was conducted at the head and the staff involved in the process of financial management in the Government District Talaud Islands. This study aimed to determine the effect of financial statement presentation and accessibility to transparency and accountability in government financial management goverment Talaud Islands.

Data analysis method used is the method of multiple linear regression, descriptive statistics test, test validity and reliability testing, test assumptions of classical, hypothesis testing ( $F$ test and $t$ test), the coefficient of determination $\left(R^{2}\right)$. To complete the overall data analysis used SPSS 20.0 software.

The results show the financial statement presentation and accessibility significantly affect the transparency and accountability of financial management. It can be seen from the equation $Y=5,425$ $++0.579 X 1$ 0.094X2. Of multiple linear regression equation shows that the financial statement presentation and accessibility positive effect on transparency and accountability in the management of the financial statements. The correlation coefficient $(R)$ obtained for $65.3 \%$ and the coefficient of determination $\left(R^{2}\right)$ of $42.7 \%$ and the remaining $57.3 \%$ or other variables not examined in this study. Results of hypothesis testing ( $F$ test) showed a significance value of 0.000 at the significant level $\alpha=$ 0.05 level test results mean $F$ states $H 0$ rejected Ha accepted. And ( $t$ test) showed for the variable XI (Regions Financial Statements) significant value for 0000 with a significant level of $\alpha=0.05$ then HO is rejected means-Ha is accepted, it means the area of financial statement presentation variables significantly affect the transparency and accountability of financial management. For the variable X2 (Aksesibilitan Regional Financial Statements) significant value of 0.526 with a significant level of $\alpha=$ 0.05 then $\mathrm{HO}$ is accepted means Ha rejected, meaning that the variable with Regional Financial Statements do not significantly affect the Transparency and Accountability of Financial Management.
\end{abstract}




\section{PENDAHULUAN}

\subsection{Alasan Pemilihan Judul}

Era globalisasi saat ini merupakan sesuatu yang tidak dapat dihindari oleh seluruh masyarakat dunia. Bangsa Indonesia sebagai bagian dari masyarakat di dunia memiliki kewajiban untuk secara terus-menerus berpartisipasi dalam mewujudkan kepemerintahan yang baik (good governance). Good Governance adalah suatu penyelenggaraan manajemen pembangunan yang sejalan dengan prinsip demokrasi, penghindaran dari salah alokasi dana investasi. Kepemerintahan yang baik setidaknya ditandai dengan tiga elemen yaitu transparansi, partisipasi dan akuntabilitas. Transparansi dibangun atas dasar kebebasan memperoleh informasi. Partisipasi maksudnya mengikutsertakan keterlibatan masyarakat dalam pembuatan keputusan baik secara langsung maupun tidak langsung melalui lembaga perwakilan yang dapat menyalurkan aspirasinya. Sedangkan akuntabilitas adalah pertanggungjawaban kepada publik atas setiap aktivitas yang dilakukan.

Pemerintah Daerah diberi kewenangan untuk mengatur dan mengurus sendiri urusan pemerintahan menurut asas ekonomi dan tugas berbantuan sesuai dengan Undang-Undang Nomor 32 Tahun 2004 tentang Pemerintah Daerah dan Undang-Undang Nomor 33 Tahun 2004 tentang Perimbangan Keuangan antara Pemerintah Pusat dan Daerah. Kedua Undang-undang ini menjadi dasar hukum dalam pelaksanaan Otonomi Daerah di Indonesia.

Pada saat dimulainya otonomi daerah harapan yang muncul adalah pemerintah daerah semakin mandiri dalam pelaksanaan kegiatan pemerintahan maupun melakukan pembangunan di daerah masing-masing. Oleh karena itu daerah juga diberi kebebasan dalam hal penyajian laporan keuangan pada pemerintah daerah dapat memberikan informasi yang digunakan sebagai dasar penyusunan anggaran pada periode berikutnya, penilaian prestasi kerja pemerintah serta alat pemotivasi.

Laporan Keuangan disusun untuk menyediakan informasi yang relevan mengenai posisi keuangan dan seluruh transaksi yang dilakukan oleh suatu entitas pelaporan dalam suatu periode pelaporan. Laporan keuangan terutama digunakan untuk membandingkan realisasi pendapatan, belanja, transfer, dan pembiayaan dengan anggaran yang telah ditetapkan, menilai kondisi keuangan, mengevaluasi efektifitas dan efisiensi suatu entitas pelaporan, dan membuat menentukan ketaatannya terhadap peraturan perundang-undangan.

Berdasarkan alasan pemilihan judul yang telah disampaikan dan penelitian yang dilakukan sebelumnya, Mulyana (2006) dengan judul Pengaruh Penyajian Neraca dan Aksesbilitasnya terhadap Transparansi dan Akuntabilitas Pengelolaan Keuangan daerah menyatakan bahwa Penyajian Neraca dan Aksesbilitas berpengaruh pada Transparansi dan Akuntabilitas Pengelolaan Keuangan Daerah. Nasution (2009) dengan judul Pengaruh Penyajian Neraca SKPD dan Aksesibilitas Laporan Keuangan Daerah Terhadap Transparansi dan Akuntabilitas Pengelolaan Keuangan Daerah di pemerintahan Propinsi Sumatera Utara menyatakan bahwa Penyajian Neraca SKPD dan Aksesbilitas berpengaruh pada Transparansi dan Akuntabilitas Pengelolaan Keuangan Daerah di Pemerintahan Propinsi Sumatera Utara. Hartina (2009) dengan judul Analisis Penyajian Laporan Keuangan Daerah Pada Pemerintahan Kabupaten Langkat menyatakan bahwa Penyajian Laporan Keuangan berpengaruh.

Sehingga penulis tertarik untuk melakukan penelitian dengan judul " Pengaruh Penyajian laporan Keuangan dan Aksesbilitasnya Terhadap Transparansi dan Akuntabilitas Pengelolaan Keuangan Daerah di Pemerintahan Kabupaten Kepulauan Talaud”.

Berdasarkan alasan pemilihan judul yang diuraikan pada sub bab sebelumnya, permasalahan pokok dalam penelitian ini dapat di rumuskan adalah Apakah Penyajian Laporan Keuangan Daerah dan Aksesibilitas Laporan Keuangan Daerah berpengaruh terhadap transparansi dan akuntabilitas Pengelolaan Keuangan Daerah di Kabupaten Kepulauan Talaud?

Analisis data menggunakan software SPSS dengan lima tahap, pertama statistik deskripstif. Tahap kedua, pengujian kualitas data. Tahap ketiga, melakukan uji penyimpangan asumsi klasik. Tahap keempat, melakukan analisis kuantitatif. Dan tahap kelima, melakukan uji hipotesis. 


\section{LANDASAN TEORI}

\subsection{Penyajian Laporam Keuangan}

Penyajian laporan keuangan merupakan hal yang sangat penting, menurut Mardiasmo (2009), pengungkapan atas informasi ini merupakan suatu elemen dasar dari transparansi fiskal dan akuntabilitas. Dalam Pernyataan Standar Akuntansi Pemerintahan (PSAP) No. 1, alinea 49, (Peraturan Pemerintah Nomor 71 Tahun 2010) dinyatakan bahwa neraca mencantumkan sekurang-kurangnya pos-pos berikut: kas dan setara kas; investasi jangka pendek; piutang pajak dan bukan pajak; persediaan; investasi jangka panjang; aset tetap; kewajiban jangka pendek; kewajiban jangka panjang; dan ekuitas dana. Informasi keuangan di dalam laporan keuangan dapat memberikan manfaat sebagai berikut: (a) meningkatkan akuntabilitas untuk paramanajer (kepala daerah dan para pejabat pemda) ketika mereka menjadi bertanggung jawab tidak hanya pada kas masuk dan kas keluar, tetapi juga pada aset dan utang yang mereka kelola; (b) meningkatkan transparansi dari aktivitas pemerintah. Pemerintah umumnya mempunyai jumlah aset yang signifikan dan utang, pengungkapan atas informasi ini merupakan suatu elemen dasar dari transparansi fiskal dan akuntabilitas. (c) memfasilitasi penilaian posisi keuangan dengan menunjukkan

semua sumber daya dan kewajiban; (d) Memberikan informasi yang lebih luas yang dibutuhkan untuk pengambilan keputusan (Mardiasmo, 2009).

\subsection{Aksesibilitas Laporan Keuangan}

Ketidakmampuan laporan keuangan dalam melaksanakan akuntabilitas, tidak saja disebabkan karena laporan tahunan yang tidak memuat semua informasi relevan yang dibutuhkan para pengguna, tetapi juga karena laporan tersebut tidak dapat secara langsung tersedia dan aksesibel pada para pengguna potensial (Jones et al, 1985) dalam Budi (2008). Oleh karena itu, pemerintah daerah harus meningkatkan aksesibilitas laporan keuangannya, tidak sekedar menyampaikannya ke DPRD saja, tetapi juga memfasilitasi masyarakat luas agar dapat mengetahui atau memperoleh laporan keuangan dengan mudah.

Akuntabilitas yang efektif tergantung kepada akses publik terhadap laporan pertanggungjawaban maupun laporan temuan yang dapat dibaca dan dipahami. Dalam demokrasi yang terbuka, akses ini diberikan oleh media, seperti surat kabar, majalah, radio, stasiun televisi, dan website (internet); dan forum yang memberikan perhatian langsung atau peranan yang mendorong akuntabilitas pemerintah terhadap masyarakat (Shende dan Bennet, 2004).

Dalam UU No. 33 tahun 2004 tentang Perimbangan Keuangan antara Pemerintah Pusat dan Pemerintah Daerah, pasal 103, dinyatakan bahwa informasi yang dimuat dalam sistem informasi keuangan daerah (SIKD) adalah data terbuka yang dapat diketahui, diakses dan diperoleh oleh masyarakat. Ini berarti bahwa pemerintah daerah harus membuka akses kepada stakeholder secara luas atas laporan keuangan yang dihasilkannya, misalnya dengan mempublikasikan laporan keuangan daerah melalui surat kabar, internet, atau cara lainnya.

\subsection{Transparansi dan Akuntabilitas Keuangan Daerah}

Reformasi dalam pemerintahan di Indonesia tidak terlepas dari semangat penegakan demokrasi. Istilah 'demokrasi' mengisyaratkan setidaknya tiga elemen esensial: transparansi, akuntabilitas dan keadilan (Shende dan Bennett dalam Budi 2006). Transparansi merupakan suatu kebebasan untuk mengakses aktivitas politik dan ekonomi pemerintah dan keputusan-keputusannya. Transparansi memungkinkan semua stakeholders dapat melihat struktur dan fungsi pemerintahan, tujuan dari kebijakan dan proyeksi fiskalnya, serta laporan (pertanggungjawaban) periode yang lalu. Akuntabilitas mengandung arti pertanggungjawaban, baik oleh orang-orang maupun badan-badan yang dipilih, atas pilihan-pilihan dan tindakan-tindakannya. Konsep keadilan berarti bahwa masyarakat diperlakukan secara sama di bawah hukum, dan mempunyai derajat yang sama dalam partisipasi politik dalam pemerintahannya.

Transparansi, akuntabilitas dan keadilan merupakan atribut yang terpisah. Akan tetapi, dua istilah yang pertama adalah tidak independen, sebab pelaksanaan akuntabilitas memerlukan transparansi. 
Sementara itu, Mohamad dalam Budi (2006) menyatakan bahwa esensi dari demokrasi adalah akuntabilitas, sedangkan esensi dari akuntabilitas adalah keterbukaan (transparansi).

Instrumen utama dari akuntabilitas keuangan adalah anggaran pemerintah, data yang secara periodik dipublikasikan, laporan tahunan dan hasil investigasi dan laporan umum lainnya yang disiapkan oleh agen yang independen.Anggaran tahunan secara khusus mempunyai otoritas legal untuk pengeluaran dana publik, sehingga proses penganggaran secara keseluruhan menjadi relevan untuk manajemen fiskal dan untuk melaksanakan akuntabilitas keuangan dan pengendalian pada berbagai tingkat operasi.

Akuntabilitas publik adalah kewajiban pihak pemegang amanah (agent) untuk memberikan pertanggungjawaban, menyajikan, melaporkan, dan megungkapkan segala aktivitas dan kegiatan yang menjadi tanggungjawabnya kepada pihak pemberi amanah (principal) yang memiliki hak dan kewenangan untuk meminta pertanggungjawaban tersebut. Akuntabilitas publik terdiri dari: (1) akuntabilitas vertikal, dan (2) akuntabilitas horizontal.

\section{GAMBARAN UMUM OBJEK PENELITIAN}

\subsection{Sekilas tentang Kabupaten Kepulauan Talaud}

Kabupaten Kepulauan Talaud merupakan bagian integral dari Propinsi Sulawesi Utara, beribukota Melonguane yang berjarak sekitar 271 mil laut dari Ibukota Propinsi Sulawesi Utara yaitu Manado. Terletak antara $3^{\circ} 38^{\prime} 00^{\prime \prime}-5^{\circ} 33^{\prime}$ 00" Lintang Utara dan $126^{\circ} 38^{\prime} 00^{\prime}$ - 127 10' 00" Bujur Timur, berada diantara Pulau Sulawesi dengan Pulau Mindanao (Republik Philipina), sehingga Kabupaten Kepulauan Talaud, bersama dengan Kabupaten Kepulauan Sangihe, di

sebut " Daerah Perbatasan ". Kemudian disamping Daerah Perbatasan, karateristik lain yang cukup signifikan membedakan Kabupaten Kepulauan Talaud dengan Kabupaten/Kota lain yakni : Daerah Kepulauan dan Daerah Tertinggal.

Kabupaten Kepulauan Talaud berdasarkan pembagian wilayah administratif Pemerintahan Daerah keadaan tahun 2010 dibagi dalam 19 Kecamatan dan 142 Desa dan 11 Kelurahan. Hingga saat ini dipimpin oleh seorang Pelaksana Tugas Bupati. Pada tingkat Kecamatan dipimpin oleh Camat dan pada tingkat Desa/Kelurahan dipimpin seorang Kepala Desa/Lurah.

\subsection{Gambaran Umum Dinas Pendapatan, Pengelolaan Keuangan dan Aset Daerah.}

Dinas Pendapatan Pengelolaan Keuangan dan Aset Daerah Kab. Kepl. Talaud sesuai dengan peraturan daerah no.6 Tahun 2008 tentang Organisasi dan Tata Kerja Dinas-Dinas Kab. Kepl Talaud, bahwa Organisasi Dinas Pendapatan Pengelolaan Keuangan dan Aset Daerah Kab. Kepl Talaud Mempunyai tugas pokok dan funsi sebagi berikut.

Tugas Pokok, Dinas Pendapatan Pengelolaan Keuangan dan Aset Daerah mempunyai tugas membantu Bupati dalam melaksanakan urusan pemerintah daerah berdasarkan asas otonomi dan tugas perbantuan dibidang Pendapatan Pengelolaan dan Aset Daerah.

Fungsi, dalam melakukan tugas Dinas Pendapatan Pengelolaan Keuanga dan Aset Daerah mempunyai fungsi sebagia berikut:

1. Perumusan Kebijaksanaan teknis dibidang pendapatan, Pengelolaan Keuangan dan Aset Daerah.

2. Penyelenggaraan urusan pemerintahan dan pelayanan umum dibidang Pendapatan, Pengelolaan Keuangan dan Aset Daerah.

3. Pembinaan dan Pelaksanaan tugas dibidang Pendapatan, Pengelolaan Keuangan dan Aset Daerah.

4. Melaksanakan tugas lain yang diberikan oleh Kepala Daerah. 


\section{ANALISIS DAN EVALUASI}

1. Hasil Penelitian

Dari semua kuesioner yang dibagikan yaitu sebanyak 71 kuesioner, yang dapat diolah dan ditabulasi untuk tujuan analisis data yaitu sebanyak 50 kuesioner. Data yang ditabulasi adalah semua tanggapan atau jawaban responden atas setiap pertanyaan yang ada dalam kuesioner. Pertanyaanpertanyaan berkaitan dengan variabel Penyajian Laporan Keuangan, Aksesibilitas laporan Keuangan, serta Transparansi dan Akuntabilitas Pengelolaan Keuangan Daerah.

Penelitian ini ditabulasi dengan menggunakan software SPSS 20.0 dan hasil penelitian menunjukkan untuk pengujian kualitas data, setiap pertanyaan dan jawaban dalam penelitian ini menyatakan Valid dan Reliabel seseuai dengan standar 0.05 dan cronbach alpha $>0.6$. Untuk uji asumsi klasik, yang terdiri dari Uji Multikolinearitas, menyatakan bahwa tidak ada multikolinearitas dengan hasil perhitungan tolerance $>0.10$ atau $V I F<10$ yaitu $0.688>0.10$ atau $1.453<10$, Uji Heteroskedastisitas, menunjukkan diagram scatterplot tidak membentuk suatu pola tertentu atau posisinya dalam keadaan menyebar.

Hasil Uji Normalitas menyatakan bahwa pada grafik data menyebar disekitar garis diagonal dan mengikuti arah garis diagonal, maka dapat dikatakan bahwa distribusi data residual normal. Hasil uji Autokorelasi dengan melihat Uji Durbin Watson adalah 1.654 sehingga dapat kesimpulannya tidak dapat disimpulkan terjadi autokorelasi.

Pengujian Statistik terdiri dari Analisis regresi berganda dengan rumus $\mathbf{Y}=\boldsymbol{\alpha}+\boldsymbol{\beta}_{\mathbf{1}} \mathbf{X}_{\mathbf{1}}+\boldsymbol{\beta}_{\mathbf{2}} \mathbf{X}_{\mathbf{2}}+\boldsymbol{\varepsilon}$, Dimana : $\mathbf{Y}=$ Transparansi dan Akiuntabilitas Pengelolaan Keuangan Daerah, $\boldsymbol{\alpha}=$ Konstanta, $\boldsymbol{\beta}_{\mathbf{1}}=$ Koefisien regresi untuk $\mathrm{X}_{1}, \boldsymbol{\beta}_{\mathbf{2}}=$ Koefisien regresi untuk $\mathrm{X}_{2}, \boldsymbol{\varepsilon}=$ Error term, $\mathbf{X}_{\mathbf{1}}=$ Penyajian Laporan Keuangan $(\mathrm{PLK}), \mathbf{X}_{\mathbf{2}}=$ Aksesibilitas Laporan Keuangan (ALK). Sehingga didapat $\mathbf{Y}=\mathbf{5 . 4 2 5}+\mathbf{0 . 5 7 9} \mathbf{P L K}+$ 0.094 ALK, Persamaan tersebut dapat dijelaskan sebagai berikut.

1. Nilai $\beta_{1}$ yang merupakan koefisien regresi dari variabel $X_{1}$ (Penyajian Laporan Keuangan) sebesar 0.579 mempunyai arti bahwa variabel Penyajian Laporan Keuangan $\left(\mathrm{X}_{1}\right)$ berpengaruh positif terhadap variabel Transparansi dan Akuntabilitas pengelolaan Keuangan Daerah (Y).

2. Nilai $\beta_{2}$ yang merupakan koefisien regresi dari variabel $\mathrm{X}_{2}$ (Aksesibilitas laporan Keuangan) sebesar 0.094 mempunyai arti bahwa variabel Aksesibilitas Laporan Keuangan $\left(\mathrm{X}_{2}\right)$ berpengaruh positif terhadap variabel Transparansi dan Akuntabilitas Pengelolaan Keuangan Daerah (Y).

Dengan demikian dapat diketahui bahwa terdapat hubungan yang kuat dan searah antara variabel bebas $\mathrm{X}_{1}$ dan $\mathrm{X}_{2}$ dengan variabel terikat $\mathrm{Y}$, dimana angka koefisien regresi yang diperoleh semuanya menunjukan angka positif $(+)$.

Hasill uji koefisien korelasi (R) menunjukkan hasil 0.653 atau $65.3 \%$ yang memberi arti bahwa terdapat hubungan yang kuat antara Penyajian Laporan Keuangan dan Aksesibilitasnya terhadap Transparansi dan Akuntabilitas Pengelolaan Keuangan Daerah. Uji koefisien Determinasi menunjukkan hasil 0.427 atau 42.7\%, dapat disimpulkan bahwa Transparansi dan Akuntabilitas Pengelolaan Keunagan Daerah (Y) mendapat kontribusi dari Penyajian Laporan keuangan $\left(\mathrm{X}_{1}\right)$ dan Aksesibilitansya $\left(\mathrm{X}_{2}\right)$ sebesar $42.7 \%$ sedangkan sisanya $57.3 \%$ mendapat kontribusi dari faktor atau variabel lain yang tidak diteliti dalam penelitian ini. Hasil Uji t menunjukkan sebagai berikut.

1. Pengujian Hipotesis Pertama $\left(\mathrm{H}_{1}\right)$

Dari Tabel 4.15, Hasil uji t untuk variabel komitmen Organisasional $\left(\mathrm{X}_{1}\right), \mathrm{t}_{\text {hitung }}=4.520$ dan $\mathrm{t}_{\text {tabel }}=$ 1.677 dan nilai signifikansi $0.000<0.05$. Karena $t_{\text {hitung }}>t_{\text {tabel }}$ dan nilai signifikansi $<0.05$ dapat disimpulkan bahwa hipotesis pertama $\left(\mathrm{H}_{1}\right)$ diterima. Hal ini menjelaskan tentang berpengaruh positif antara variabel Penyajian Laporan Keuangan terhadap variabel Transparansi dan akuntabilitas Pengelolaan keuangan Daerah.

2. Pengujian Hipotesis Kedua $\left(\mathrm{H}_{2}\right)$

Dari Tabel 4.15, Hasil uji t untuk variabel Peran Manajer pengelolaan Keuangan Daerah $\left(\mathrm{X}_{2}\right)$, $\mathrm{t}_{\text {hitung }}$ $=0.639$ dan $t_{\text {tabel }}=1.677$ dan nilai signifikansi $0.526>0.05$. Karena $t_{\text {hitung }}>t_{\text {tabel }}$ dan nilai signifikansi $>0.05$ dapat disimpulkan bahwa hipotesis kedua $\left(\mathrm{H}_{2}\right)$ ditolak. Hal ini menjelaskan 
tentang tidak pengaruh antara variabel Aksesibilitas Laporan keuangan Terahadap variabel Transparansi dan Akuntabilitas Pengelolaan keuangan Daerah.

Hasil uji $\mathrm{F}$ menunjukkan bahwa Dari uji ANOVA didapat nilai $F_{\text {hitung }}$ sebesar 17.483 dan $F_{\text {tabel }}$ sebesar 3.68 dengan nilai signifikansi 0.000 . Karena $F_{\text {hitung }}>F_{\text {tabel }}$ dan nilai signifikansi $<0.05$, maka variabel Penyajian Laporan Keuangan dan Aksesibilitasnya berpengaruh signifikan terhadap variabel Transparansi dan Akuntabilitas Pengelolaan Keuangan Daerah Komitmen Organisasi dan peran Manajer Pengelolaan Keuangan Daerah.

\section{Pembahasan}

\section{Pengaruh Penyajian Laporan Keuangan terhadap Transparansi dan Akuntabilitas Pengelolaan Keuangan Daerah}

Hasil pengujian hipotesis menunjukkan bahwapenyajiaan laporan keuangan terhadap transparansi dan akuntabilitas pengelolaan keuangan daerah berpengaruh positif sebesar 4.520 pada tingkat signifikansi 0.000 , yang berarti signifikan karena berada dibawah nilai signifikansi yang dipersyaratkan yaitu 0.05 , sehingga dapat disimpulkan bahwa penyajian laporan keuangan berpengaruh terhadap transparansi dan akuntabilitas pengelolaan keuangan daerah.

Dari hasil pengujian hipotesis pertama menyatakan bahwa penyajian laporan keuangan berpengaruh positif dan signifikan terhadap transparansi dan akuntabilitas pengelolaan keuangan daerah. Ini menunjukkan bahwa pemerintah menyajikan laporan keuangan secara wajar, mengungkapkan secara lengkap dan aktivitas dari pemerintah sesuai dengan pernyataan standar akuntansi pemerintah (PSAP) serta menentukan dan membuktikan kesesuaian dengan peraturan keuangan yang terkait dan syarat-syarat kontraktual agar laporan keuangan yang disajikan dapat memenuhi harapan pengguna.

\section{Pengaruh Aksesibilitas Laporan Keuangan terhadap Transparansi dan Akuntabilitas Pengelolaan Keuangan Daerah}

Hasil pengujian hipotesis kedua menunjukkan bahwa Aksesibilitas tidak berpengaruh terhadap transparansi dan akuntabilitas pengelolaan keuangan daerah sebesar 0.639 pada tingkat signifikansi 0.526 , yang berarti tidak signifikan karena berada diatas nilai signifikansi yang disyaratkan yaitu 0.05 , sehingga dapat disimpulkan bahwa aksesibilitas laporan keuangan tidak dapat meningkatkan transparansi dan akuntabilitas pengelolaan keuangan daerah.

Hal ini mengindikasikan bahwa pemerintah daerah tidak membuka akses kepada stakeholde secara luas atas laporan keuangan yang dihasilkannya. Hal ini disebabkan karena masih adanya informasiinformasi dan kebijakan-kebijakan yang dibuat pemerintah yang menjadi rahasia negara/daerah/SKPD tidak disajikan dalam laporan keuangan yang dibuatnya. Sehingga aksesibilitas laporan keuangan daerah masih sangat sulit untuk didapat dan diterima oleh masyarakat.

\section{Pengaruh Penyajian Laporan Keuangan dan Aksesibilitasnya terhadap Transparansi dan Akuntabilitas Pengelolaan Keuangan Daerah.}

Hasil pengujian hipotesis ketiga menyatakan bahwa penyajian laporan keuangan dan aksesibilitasnya berpengaruh positif dan signifikan terhadap tranparansi dan akuntabilitas pengelolaan keuangan daerah. Hal ini berarti bila laporan keuangan yang disajikan sesuai dengan standar akuntansi pemerintah dan aksesibilitas laporan keuangan secara lengkap mudah didapat dan diterapkan secara bersama-sama maka transparansi dan akuntabilitas pengelolaan keuangan daerah semakin baik serta terwujudnya pemerintahan yang baik (good governance). Adanya laporan keuangan lengkap dan akses laporan keuangan yang baik dibuat pemerintah maka informasi akan laporan keuangan semakin mudah didapat dan diterima oleh stakeholder, sehingga transparansi dan akutabilitas laporan keuangan smakin baik. 
Tabel 1

Coefficients $^{\mathrm{a}}$

\begin{tabular}{|l|r|r|}
\hline \multirow{2}{*}{ Model } & \multicolumn{2}{|c|}{ Collinearity Statistics } \\
\cline { 2 - 3 } & \multicolumn{1}{|c|}{ Tolerance } & \multicolumn{1}{|c|}{ VIF } \\
\hline (Constant) & .688 & 1.453 \\
Penyajian Laporan Keuangan Daerah & .688 & 1.453 \\
Aksesibilitas Laporan Keuangan & .68 & \\
\hline
\end{tabular}
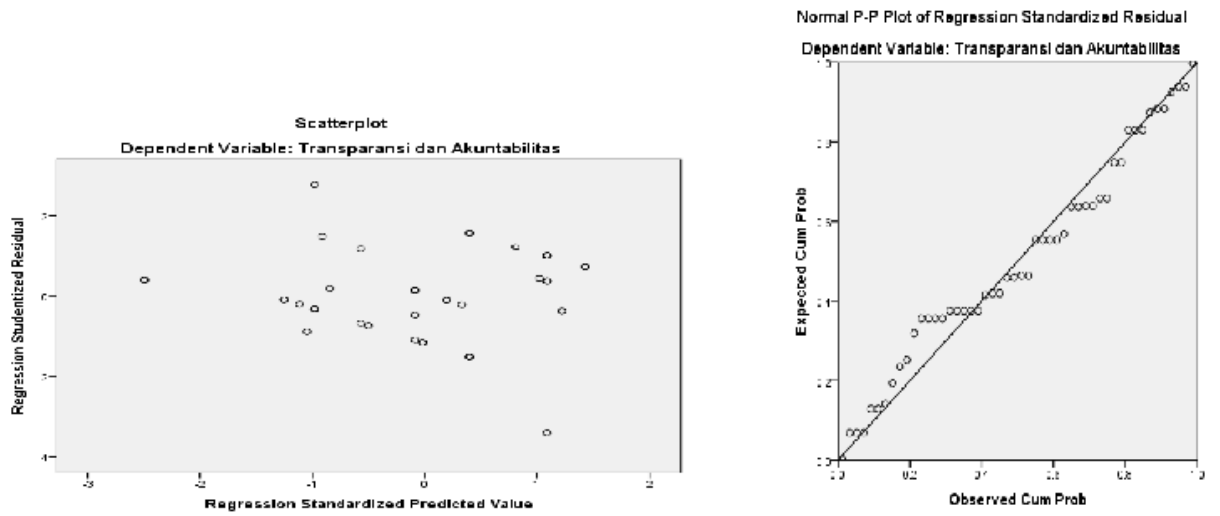

Tabel 2

Model Summary $\mathbf{b}^{\mathrm{b}}$

\begin{tabular}{|c|c|r|r|r|r|}
\hline $\begin{array}{c}\text { Mode } \\
1\end{array}$ & $\mathrm{R}$ & $\mathrm{R}$ Square & $\begin{array}{c}\text { Adjusted R } \\
\text { Square }\end{array}$ & $\begin{array}{c}\text { Std. Error of } \\
\text { the Estimate }\end{array}$ & $\begin{array}{c}\text { Durbin- } \\
\text { Watson }\end{array}$ \\
\hline 1 & $.653^{\mathrm{a}}$ & .427 & .402 & 1.65498 & 1.654 \\
\hline
\end{tabular}

Tabel 3.Coefficients ${ }^{\mathrm{a}}$

\begin{tabular}{|c|c|c|c|c|c|}
\hline \multirow[t]{2}{*}{ Model } & \multicolumn{2}{|c|}{ Unstandardized Coefficients } & \multirow{2}{*}{$\begin{array}{c}\text { Standardized } \\
\text { Coefficients } \\
\text { Beta } \\
\end{array}$} & \multirow[t]{2}{*}{$\mathrm{T}$} & \multirow[t]{2}{*}{ Sig. } \\
\hline & $\mathrm{B}$ & Std. Error & & & \\
\hline (Constant) & 5.425 & 2.127 & & 2.550 & .014 \\
\hline $1 \begin{array}{l}\text { Penyajian Laporan } \\
\text { Keuangan Daerah }\end{array}$ & .579 & .128 & .602 & 4.520 & .000 \\
\hline $\begin{array}{l}\text { Aksesibilitas } \\
\text { Laporan Keuangan }\end{array}$ & .094 & .148 & .085 & 639 & .526 \\
\hline
\end{tabular}

Tabel 4. ANOVA ${ }^{\mathrm{a}}$

\begin{tabular}{|l|c|c|c|c|c|}
\hline Model & $\begin{array}{c}\text { Sum of } \\
\text { Squares }\end{array}$ & Df & Mean Square & F & Sig. \\
\hline
\end{tabular}




\begin{tabular}{|l|r|r|r|r|r|}
\hline \multicolumn{1}{|l|}{ Regression } & 95.768 & 2 & 47.884 & 17.48 & $.000^{\mathrm{b}}$ \\
1 & & & 3 & \\
Residual & 128.732 & 47 & 2.739 & & \\
Total & 224.500 & 49 & & & \\
\hline
\end{tabular}

\section{PENUTUP}

\subsection{Kesimpulan}

Berdasarkan hasil pembahasan pada bab sebelumnya, maka penulis mengambil kesimpulan mengenai Pengaruh penyajian Laporan keuangan daerah dan aksesibilitasnya terhadap transparansi dan akuntabilitas pengelolaan keuangan daerah sebagai berikut :

1. Berdasarkan pembahasan hasil analisa dalam penelitian ini maka persamaan regresi berganda adalah sebagai berikut :

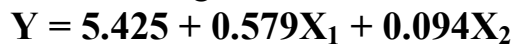

Hasil analisa regresi liniear berganda menunjukkan bahwa Penyajian Laporan Keuangan Daerah $\left(\mathrm{X}_{1}\right)$ dan Aksesibilitasnya $\left(\mathrm{X}_{2}\right)$, secara bersama-sama atau serentak berpengaruh signifikan dan positif terhadap Transparansi dan Akuntabilitas Pengelolaan Keuangan Daerah di Pemerintahan Kabupaten Kepulauan Talaud

2. Secara parsial variabel Penyajian Laporan Keuangan Daerah $\left(\mathrm{X}_{1}\right)$ mempunyai pengaruh positif terhadap Transparansi dan Akuntabilitas Pengelolaan Keuangan Daerah di Pemerintahan Kabupaten Kepulauan Talaud, dan dapat di katakan bahwa variabel Penyajian Laporan Keuangan Daerah memiliki pengaruh yang kuat. Sedangkan variabel Aksesibilitas Laporan Keuangan Daerah $\left(\mathrm{X}_{2}\right)$ tidak berpengaruh dan tidak signifikan terhadap Transparansi dan Akuntabilitas Pengelolaan Keuangan Daerah di Pemerintahan Kabupaten Kepulauan Talaud.

3. Hasil analisa regresi secara keseluruhan menunjukkan $\mathrm{R}$ sebesar 0.653 yang berarti bahwa korelasi atau hubungan antara Penyajian Laporan Keuangan Daerah dan Aksesibilitasnya dengan Transparansi dan Akuntabilitas Pengelolaan Keuangan Daerah memiliki hubungan yang kuat sebesar $65.3 \%$. Sedangkan nilai $\mathrm{R}$ square atau nilai koefisien determinan sebesar 0.427 yang berarti bahwa variabel dependen (Transparansi dan Akuntabilitas Pengelolaan Keuangan Daerah) mampu dijelaskan oleh variabel independen (Penyajian Laporan Keuangan Daerah dan Aksesibilitasnya) sebesar 42.7\% dan selebihnya 57.3\% (100\% - 42.7\% = 53.7\%) dapat dijelaskan oleh faktor - faktor lain tidak diteliti dalam penelitian ini.

\subsection{Saran}

Berdasarkan kesimpulan, penulis dapat memberikan saran sebagai berikut :

1. Dari hasil penelitian diketahui bahwa Penyajian Laporan Keuangan Daerah yang lebih dominan dibandingkan Aksesibilitasnya. Karena itu, Pemerintah Daerah diharapkan bisa lebih terbuka lagi kepada masyarakat atas laporan keuangan yang dibuat agar masyarakat dapat mengakses dan mengetahui semua pendapatan, belanja daerah dan aset yang dimilki oleh daerah sehingga Transparansi dan Akuntabilitas Pengelolaan Keuangan Daerah dapat tercipta di Pemerintahan Kabupaten Kepulauan Talaud.

2. Untuk tahun-tahun anggaran selanjutnya hendaknya Pemerintah Daerah dapat menyajikan Laporan Keuangan Daerah yang lebih baik lagi dan secara lengkap dan disusun berdasarkan standar akuntansi pemerintah (SAP) dan dapat di akses oleh penggunanya/masyarakat.

3. Dengan adanya tuntutan agar pemerintah daerah dapat membuat laporan keuangan dengan baik dan secara lengkap setidaknya pemerintah daerah lebih telitih lagi dalam perekrutan pengawai yang memilki latar belakang di bidang akuntansi dan keuangan. 


\section{DAFTAR PUSTAKA}

Bastian, Indra, (2008), Akuntansi Sektor Publik, Suatu Pengantar, Jakarta, Penerbit Erlangga.

Halim, Abdul, (2008), Akuntansi Keuangan Daerah, Jakarta, Penerbit Salemba Empat.

Halim, A, dan T. Damayanti, (2011), Akuntansi Sektor Publik, Pengelolaan Keuangan Daerah, Edisi 3, Yogyakarta, UPP STIM YKPN.

Mardiasmo, (2009), Akuntansi Sektor Publik. Yogyakarta, Penerbit Andi.

Hartina, Silka, (2009), Analisis Penyajian Laporan Keuangan Daerah pada Pemerintahan Kabupaten Langkat, Skripsi S1, Medan, Fakultas Ekonomi Universitas Sumatera Utara.

Lembaga Administrasi Negara, (2003), Pedoman Penyusunan Pelaporan Akuntabilitas Kinerja Instansi Pemerintah.

Nasution, Saufi, (2009), Pengaruh Penyajian Neraca SKPD dan Aksesibilitas Laporan Keuangan Daerah Terhadap Transparansi dan Akuntabilitas Pengelolaan Keuangan Daerah, Skripsi S1, Medan, Fakultas Ekonomi Universitas Sumatera Utara.

Mulyana, Budi, (2006), "Pengaruh Penyajian Neraca Daerah dan Aksesibilitas Laporan Keuangan Terhadap Transparansi dan Akuntabilitas Pengelolaan Keuangan Daerah", Jurnal Akuntansi Pemerintahan, Volume 2 No.1, Mei 2006.

Mardiasmo, (2009), Akuntansi Sektor Publik, Yogyakarta, Penerbit Andi.

Mardiasmo, (2011), Otonomi dan Manajemen Keuangan Daerah, Good

Governance. Penerbit Andi, Yogyakarta.

Mardiasmo, (2006). "Perwujudan Transparansi dan Akuntabilitas Publik Melalui Akuntansi Sektor Publik, Suatu Sasaran Good Governance”, Jurnal Akuntansi Pemerintah, Volume 2 No.1, hal 1-17.

Mulyana, Budi, (2006). "Pengaruh Penyajian Neraca Daerah dan Aksesibilitas Laporan Keuangan Terhadap Transparansi dan Akuntabilitas Pengelolaan Keuangan Daerah”, Jurnal Akuntansi Pemerintahan, Volume 2, No.1, Mei 2006.

Renyowijoyo, Muindro, (2008), Akuntansi sektor Publik Organisasi Non Laba, Jakarta, Penerbit Citra Wacana Media.

Darise, N, (2008), Akuntansi Keangan Daerah (Akuntansi Sektor Publik), Jakarta, Penerbit PT.Macanan Jaya Cemerlang.

Republik Indonesia.Undang-undang No. 32 Tahun 2004 Tentang Pemerintah Daerah.

Republik Indonesia, Undang-undang No. 33 Tahun 2004 Tentang Perimbangan antara Keuangan Pemerintah Pusat dan Pemerintah Daerah.

Republik Indonesia, Undang-undang No. 17 Tahun 2003 Tentang Keuangan Daerah.

Republik Indonesia, Undang-undang No. 1 TentangPerbendaharaan Negara.

Republik Indonesia, Undang-undang No. 15 Tahun 2004 Tentang Pemeriksaan Pengelolaan dan Tanggung Jawab Keuangan Negara.

Republik Indonesia,PeraturanPemerintah No. 24 Tahun 2005 Tentang Standar Akuntansi Pemerintahan.

Republik Indonesia, PeraturanPemerintah No. 58 Tahun 2005 Tentang Pengelolaan Keuangan Daerah. Santosa, Purbayu Budi, dan Ashari, (2005), Analisis Statistik denganMicrosoft Excel dan SPSS, Edisi II, Yogyakarta, PenerbitAndi.

Sugiyono, (2009), Metode Penelitian Bisnis, Penerbit: Alfabeta, Yogjakarta.

Sugiyono, (2008), Statistik untuk Penelitian, cetakan kesembilan, Alfa Beta, Bandung

Wijaya, Toni, (2010), Analisis Statistik Multivariat, Bandung, Alfabeta.

http://www.google.co.id: Jurnal Akuntansi Pemerintahan

http://www.wikipedia.co: Jurnal Akuntansi Pemerintahan. 